\title{
Profile of Scientific Literacy Skills in Junior High School One Roof
}

\author{
Sifak Indana \\ Biology Department, Faculty of Mathematics and Natural Sciences, Universitas Negeri Surabaya \\ sifakindana@unesa.ac.id \\ Rudiana Agustini \\ Chemistry Department, Faculty of Mathematics and Natural Sciences, Universitas Negeri Surabaya \\ Yuni Sri Rahayu \\ Biology Department, Faculty of Mathematics and Natural Sciences, Universitas Negeri Surabaya
}

\begin{abstract}
This research aimed to describe student scientific literacy skills with the concept of interaction between living things and environment. The research used quantitative descriptive method implemented at SMPN Satu Atap Kenduruan with subject of students grade VII which were determined by cluster random sampling. The instrument used was science literacy test consisting of 25 items of multiple choice and essays from competence and knowledge domains. The results showed that the percentage of student scientific literacy from competence domain skills was $22 \%$, while from student knowledge domain was $34 \%$. The percentage of both domains was still below $50 \%$ of the total number of the students. In other words, scientific literacy skills of students in SMPN Satu Atap Kenduruan were categorized as low.
\end{abstract}

Keywords - Scientific literacy skills, competence domain, knowledge domain, science learning, SMPN 1 Atap Kenduruan.

\section{INTRODUCTION}

Scientific literacy is defined as the ability to use issues and ideas related to science as a reflective citizen [1]. The science literacy in PISA includes 4 domains, namely, context, knowledge, competence and attitude of science [1,2]. The context domain includes the personal context; local and global; competence domain includes aspects of the ability to explain scientific phenomena, evaluate and design scientific research, and interpret data and scientific evidence; knowledge domain includes aspects of content knowledge and epistemic knowledge; the domain of one's attitude toward science is characterized by their attachment, concern and response in science and technology and the issues that affect them in real situations [1].

According to the National Research Council [3] the low contribution of science learning to the success of citizens is due to the release of science learning from the social context, emphasizing only the mastery of the material, and the inappropriate use of assessments so that citizens are only prepared to master knowledge. In the learning process, students should know the relevance of science learning to everyday life and social life. Science learning in schools should be directed to understanding of the importance of science when it is associated with past, present or future societies [4]. In addition, one of the factors that allegedly led to the low achievement of science literacy in Indonesia is the selection of learning resources, such as textbooks. Based on the previous study $[5,6]$, it was found that textbook content of physics in junior high school which is widely used in Bandung city has unbalanced aspects of scientific literacy.

Scientific literacy is for all students, regardless whether the students are become a scientist or not [7]. Science literacy can assist students in addressing and making decisions related to science issues in life as well as developing knowledge, skills, and using science as citizens and individuals [8]. Students are literate when are able to apply concepts or facts obtained in school with natural phenomena occurring in everyday life [9]. Students with less science literacy skills are able to solve problems in simple and familiar situations, while students with more developed literacy skills are able to solve problems in complex and less familiar situations [10]. Therefore the ability of science literacy must be owned by all students including those who study in junior high school one roof

School one roof or "Satu Atap" schooling is an educational model which is different from other elementary and junior high schools because the implementation of the teaching and learning processes occur in one place, instead of moving to other location for those two type of schooling. This model is designed for educational institutions to be closer to the most accessible to society [11]. The government hopes no more school-aged children not attending school because of school distance. However, the quality of education in "Satu Atap" and other School in general is far from ideal, as happened in SMPN "Satu Atap" Karangploso Batu-Malang and Satu Atap School in Kokop Bangkalan Village, that was no single 
student was passed in 2010 national exam. This indicates that students of Satu Atap School do not master the science subject which includes in the national exam. One of the reasons for such a failure is the limited quality of human resources. This is in accordance with the results of Rahmasari's research [12] which states that the limiting factor in the implementation of primary and junior high schools of "Satu Atap (SATAP)" is the insufficient number of teachers and educational administration personnel.

In contrast, regular schools provide qualified human resources, equal amount of high-achieving and low-achieving students, adequate facilities, and easy-to-reach location. Therefore, a breakthrough in science learning process in primary and secondary schools "Satu Atap" needs to be done in terms of preparing teacher's learning process plan. Empowerment of teachers in primary and junior high schools "SATAP" should be undertaken to overcome barriers in applying school policies in the learning process [12]. In addition, it is necessary to pay attention to the lack of facilities in schools, such as no LCD projector, no internet connection and no inquiry model implementation in science subjects in "SATAP" elementary and junior high school. Inhibiting factors from the implementation of learning activities in the elementary and junior high schools of "SATAP" was not only from the lack of teachers and educational personnel, but also from the facilities and infrastructure that are inadequate [12]. Muhafid [13] stated that those insufficiencies occur because the teachers come from various disciplines and limited learning tools, media, and science learning resources for teachers and students.

Based on the problems above that happend in "SATAP" schools, it is important to describe the science literacy skills of Satu Atap students for the next action. So, the purpose of this research was to describe the student scientific literacy skills of SMPN Satu Atap in Kenduruan. Student scientific literacy skills can be known by scientific literacy test.

\section{METHOD}

This research used quantitative descriptive method implemented at SMPN one roof. The sample used in this research was sixty students at grade VII that determined by cluster random sampling. Instrument research used was the instrument of scientific literacy test that consist of 15 items of multiple choice and 10 item of essays. Scientific literacy skills measured in terms of knowledge domain and competency domain. Based on the two domains are then compared between number of students who answered correctly and students who answered wrong based on the percentage analysis. The data obtained was used to analyze the level of students' scientific literacy.

\section{RESULT}

A. Level of scientific literacy skills of the competence domain

Competence domain of scientific literacy test that proposed to the students was based on the indicators that already established in PISA 2015. The essay questions of number 1,3,6 and 7 contain sub domains which explain the phenomenon scientifically. The questions of number 5 and 9 contains sub domain of evaluation and design of scientific discoveries. While the questions of number $11,12,13$, and 14 contain sub domain of interpretion data and scientific evidence. The results of the answers analysis of 60 students on the scientific literacy competence domain are shown in Figure 1 .

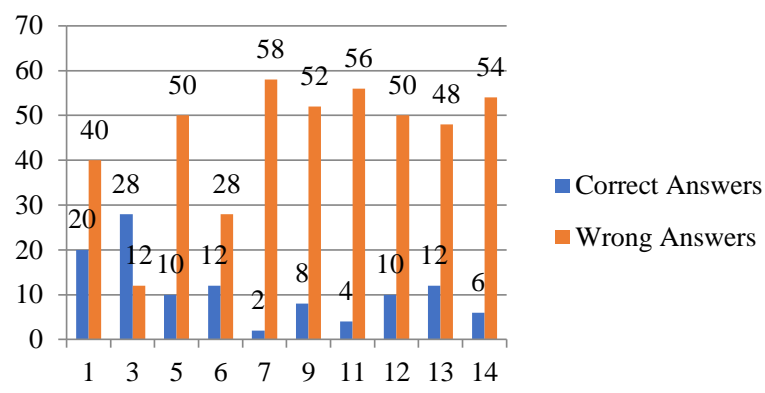

Figure 1. Graphic the number of students who answer the competence domain of science literacy

Figure 1 showed the number of students who answered correctly on the scientific literacy questions of number $1,5,6,7,9,11,12,13$ and 14 at competence domain. The most amount of correct answer of students is question number 3, while on the number 7 students most slightly answer correctly. Only one problem that can be answered more than $50 \%$ of students is the number 3 . The result of the percentage of students correct answers to scientific literacy questions on the competence domain was presented in table 1 .

\section{TABLE I. PERCENTAGE OF STUDENTS' CORRECT ANSWERS TO} EACH COMPETENCY SUB DOMAIN

\begin{tabular}{|l|c|c|}
\hline \multicolumn{1}{|c|}{ Competency sub domain } & $\begin{array}{c}\text { Number of } \\
\text { questions }\end{array}$ & $\begin{array}{c}\text { Percentage of students } \\
\text { correct answers (\%) }\end{array}$ \\
\hline $\begin{array}{l}\text { Explain the phenomenon } \\
\text { scientifically }\end{array}$ & 4 & 34 \\
\hline $\begin{array}{l}\text { Evaluate and design scientific } \\
\text { discoveries }\end{array}$ & 2 & 13 \\
\hline $\begin{array}{l}\text { interpret the data and evidence } \\
\text { scientifically }\end{array}$ & 4 & 15 \\
\hline
\end{tabular}

Table 1 showed that the percentage of students who answered correctly on the questions of the sub domain explain the phenomenon scientifically as much as $34 \%$ of the question 4. Percentage of students who answered correctly on the sub domain question evaluate and and design the scientific discovery was $13 \%$ of 2 questions. While the sub domain interpret the data and evidence scientifically, students who answered correctly was $15 \%$ of 4 questions. The percentage results were obtained from the comparison of the average 
number of students scores with the maximum scores of the correct answer.

\section{B. Level of scientific literacy skills of the knowledge domain}

The scientific literacy questions of the knowledge domain used in this study are in accordance with the criteria and indicators set by PISA 2015. Questions of number 2, 4 and 8 contain the content of knowledge sub-domain. The sub domain of procedural knowledge is found in questions of number 10, 15, 19, and 20. While the sub domain of epistemic knowledge is found in questions 16,17 and 18. The analysis results of 60 students' answers on the scientific literacy knowledge domain are shown in Figure 2.

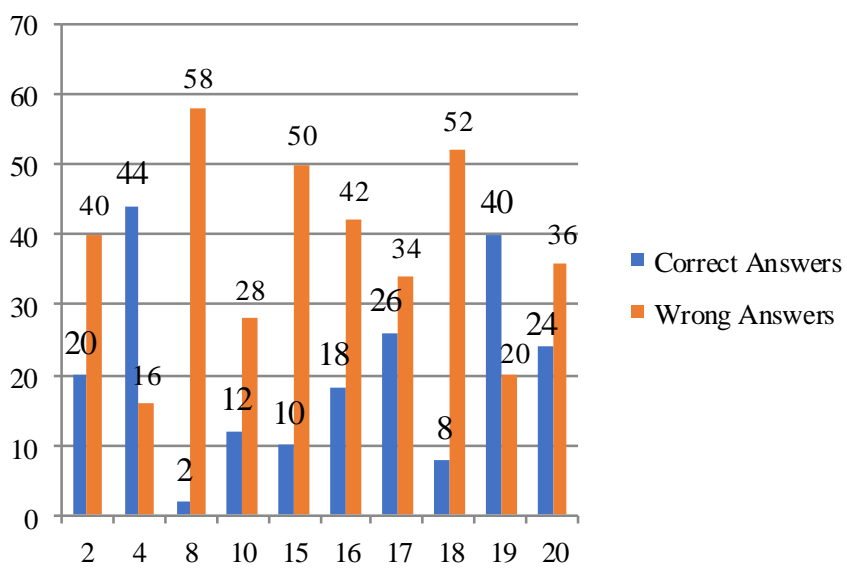

Figure 2. The graphic of the students number who answered science literacy questions of knowledge domain.

Figure 2 showed that the number of students who answered incorrectly are larger than the number of students who answered correctly on domain literacy questions was number 2, 8, 10, 15, 16, 17, 18, and 20. Question 4 and 19 indicate the number of students who answered correctly more than the incorrect answer. The fewer number of students who answered correctly was on number 8 . There are 2 questions answered more than $50 \%$ of the number of students was question number 4 and 19. The results of the percentage of students correct answer of scientific literacy questions on the domain of knowledge were presented in table 2 .

TABLE II. THE PERCENTAGE OF STUDENT CORRECT ANSWER FOR EACH KNOWLEDGE DOMAIN

\begin{tabular}{|c|c|c|}
\hline Knowledge sub domain & $\begin{array}{c}\text { Number of } \\
\text { questions }\end{array}$ & $\begin{array}{c}\text { Percentage of students } \\
\text { correct answer (\%) }\end{array}$ \\
\hline Content knowledge & 3 & 37 \\
\hline Procedural knowledge & 4 & 36 \\
\hline Epistemic knowledge & 3 & 29 \\
\hline
\end{tabular}

Table 2 showed that the percentage of students who answered correctly on the content sub domain was $37 \%$ of 3 questions. The percentage of students who answered correctly on the questions of procedural sub domains was $36 \%$ of the 4 questions, while the percentage of the epistemic sub domain was $29 \%$ of 3 questions. The percentage was obtained from the comparison of the average number of student achievement scores with the maximum score of the students correct answers.

\section{DISCUSSION}

Based on the results of scientific literacy studies conducted by PISA, it was illustrated that the ability of Indonesian students in competing at the International level should be improved. In recent results of PISA, Indonesia has been ranked in low position among the other countries participating in PISA. The science literacy scores of Indonesian students was around 400 points, that mean the Indonesian students was only able to remember scientific knowledge based on simple facts (such as names, facts, terms, simple formulas) and use general scientific knowledge to attract or evaluate a conclusion [14]. The concept of scientific literacy expects the students to have high senses of concern for themselves and their environment in dealing with the problems of everyday life and making decision based on the scientific knowledge.

The definition of scientific literacy in PISA 2012 is related to (1) individual scientific knowledge and ability to use the knowledge to identify problems, acquire new knowledge, explain scientific phenomenone, and draw conclusions based on evidence related to scientific issues; (2) the understanding the main characteristics of knowledge built on human knowledge and inquiry; (3) realizing how science and technology form the material, the intellectual and cultural environment; and (4) the willingness to engage in issues and ideas relating to science [2].

The competence domains based on PISA 2015 measured in this study include a sub-domain of ability to explain the scientific phenomenone, evaluate and plan scientific research, and interpret data and evidence scientifically [1]. These three sub domains are measured through multiple choice questions and essays to find out the students' mastery of science literacy in the competence domain. The result of the analysis showed that $34 \%$ of students capable of answering questions correctly and these are interrelated to explaining phenomenon scientifically. This indicates that the students' scientific literacy skills are dominant in the ability to recognize and remember concepts, predict hypotheses, and to apply scientific knowledge in everyday life [1].

The result of scientific literacy skills of competence domain that least controlled by students was interpretation the data and scientific evidence that was $13 \%$ of students answer correctly. This showed that the students' science literacy skills was less in the ability to manage data that obtained in the form of tables, diagrams, or graphs; analyze data and draw conclusions appropriately; interpret text or science-related discourse from various sources (newspapers, internet, or journals); and distinguish between scientific arguments and arguments without scientific evidence [1].

Knowledge domains based on PISA 2015 include aspects of content knowledge, procedural knowledge and epistemic knowledge [1]. The analysis result of the showed that the science literacy skills of the knowledge domain of the content sub domain was $37 \%$ higher than the other sub domains. This 
is supported by research which mentioned the concept of knowledge aspect is higher than the science knowledge aspect in analyzing the text or articles and aspects of problem solving [15]. Based on cognitive learning theory, students use their initial knowledge to process new information by linking the new information with their initial knowledge [16]. Levels of cognitive aspects contained in the student's memory affect the ability of students in identifying scientific issues. The result of the percentage of science literacy skills in the epistemic sub domain is lowest compared to the other, that is $29 \%$. This explained that an understanding of the functions and roles of students in science knowledge was still less applied in the learning of life [1].

The science literacy skills in both domains showed less than $50 \%$ percentage, so it can be stated that science literacy skills of SMPN Satu Atap Kenduruan was low. Other supporting studies also mention that the science literacy skills in junior high school was at the low category [2]; [17]; [18]; [19]. The low ability of science literacy makes students difficult to address and make decisions related to science issues in everyday life.

Science literacy can be a benchmark for the future determination of students career, even if the student is not involved in the science [20]. The low of science literacy can be enhanced by appropriate handling, for example by pay more attention to the characteristics and potential of the students, developing appropriate teaching materials, developing appropriate instruments, managing good learning activities, and learning strategies that needed [21]. Learning that is able to arouse students 'curiosity about the topic of learning and encourage the students to solve the problems that presented by the teacher is believed to be able to build the science process skills which is part of the competence aspect of science literacy.

\section{CONCLUSION}

Based on the results and discussion, it can be concluded that the students' scientific literacy skills of SMPN Satu Atap Kenduruan was low with the percentage of competency domain of $22 \%$ and knowledge domain of $34 \%$. The percentage of both domains was still below $50 \%$ of the total number of students. From that conclusion it is necessary to make an appropriate strategies and learning methods to improve the students' scientific literacy skills of Satu Atap schools.

\section{REFERENCES}

[1] OECD, Assessing Scientific, Reading and Mattematical Literacy A Framework for PISA, Paris: OECD Publishing, 2016.
[2] OECD, Pisa 2012 Result in Focus What 15-Year-Olds Know and What They can Do With What They Know, Paris: OECD Publishing, 2014.

[3] National Research Council, National Science Education Standards, Washington DC: The National Academies Press, 1996.

[4] J. Hoolbrook and R. Miia, "The meaning of literacy science. International", Journal of Environment \& Science Education, vol. 4, no. 3, pp. 275-288, 2009.

[5] I. M. Sari, "Perbandingan konten aspek literai sains buku teks sains yang banyak dipakai di kota bandung dengan buku teks sains terbitan luar negeri”, Prosiding Simposium Nasional Inovasi Pembelajaran dan Sains 2014. Bandung. Prodi Magister Pengajaran Fisika FMIPA ITB, pp. 308 311, 2014.

[6] I. M. Sari, "Profil konten buku teks pelajaran fisika SMP di kota Bandung berdasarkan kategori literasi sains", Prosiding Simposium Nasional INovasi dan Pembelajaran Sains 2014 Bandung, 2014.

[7] G. E. Deboer, "Scientific literacy: Another Look St its Historical Ana contemporary meaning Ana Its Relationship to Science Education Reform", Journal of Research in Science Teaching, vol. 37, pp. 582-601, 2000 .

[8] American Association for the Advancement of science, Benchmarks for Science literacy, New York: Oxford University Press, 1993.

[9] G. Anggraini, "Analisis Kemampuan literasi Sains Siswa SMA Kelas X di Kota Solok", Prosiding Mathematic and Science Forum, 2014.

[10] S. Rahayu, "Revitalisasi Scientific Approach dalam kurikulum 2013 untuk meningkatkan literasi sains: Tantangan dan Harapan”, Seminar Nasional Kimia dan Pembelajaran, 2014.

[11] M. Fadjri, "Model Sekolah Satu Atap sebagai Implementasi dari Inovasi di Bidang pendidikan”, Jurnal Online, 2009.

[12] E. Rahmasari, "Implementasi Kebijakan SD-SMP Satu Atap Di Desa canggal Kecamatan Candiriti kabupaten Temanggung”, Journal Universitas negeri Yogyakarta, vol. 3, no. 5, pp. 100-109, 2014.

[13] Muhafid, "Pengembangan modul IPA terpadi Berpendekatan Keterampilan proses pada tema Bunyi di SMP kela VIII", Unnes Physics Education Journal, vol. 1, no. 1, pp. 33-40, 2013.

[14] N. Y. Rustaman, H. Firman, and Kardiawarman, "Literasi Sains Anak Indonesia 2000", Laporan Eksekutif. Bahan Seminar Nasional di Jakarta, 2004.

[15] Y. Pantiwati and Husamah, "Analisis kemampuan literasi sains siswa SMP kota Malang", Prosiding konferensi ilmiah tahunan himpunan evaluasi pendidikan Indonesia (HEPI), 2014.

[16] D. H. Schunk, Teori-teori Pembelajaran: Perspektif Pendidikan, Yogyakarta: Pustaka Pelajar, 2012.

[17] A. H. Odja and C. S. Payu, "Analisis kemampuan awal literasi sais siswa pada konsep IPA", Prosiding seminar nasional kimia, jurusan kimia FMIPA Universitas Nageri Surabaya, Surabaya, 20 September 2014.

[18] Nadhifatuzzahro, Dalin, Setiawan, Beni, and E. Sudibyo, "Kemampuan literasi sains siswa kelas VII-B SMP Negeri Sumobito melalui pembuatan Jamu Tradisional", Seminar Nasional Fisika dan pembelajaran, 2015.

[19] L. Rizkita, H. Suwono, and S. Herawati, "Analisis kemampuan awal literasi sains siswa SMA Kota Malang”, Prosiding Seminar Nasional II, 2016.

[20] L. Huann-shyang, Z. R. Hong, and T. C. Huang, "The Role of Emotional Factors in Building Public Scientific Literacy and Engagement with Science", International Journal of Science Education, vol. 34, no. 1,pp. 25-42, 2011.

[21] A. Safitri, Erman, and S. Admoko Setyo, "Pendekatan saintifik untuk meningkatkan literasi sains SMP”, Ejournal Unesa, 2016. 